\title{
Hypoxia Induces a Specific Set of Stress Proteins in Cultured Endothelial Cells
}

Leslie H. Zimmerman, Roy A. Levine, and Harrison W. Farber

Pulmonary Center, Boston University School of Medicine, Boston, Massachusetts 02118

\begin{abstract}
Vascular endothelial cells (EC) are the initial cells within the vascular wall exposed to decreases in blood ambient oxygen concentration. The mechanisms by which they tolerate low levels of oxygen are unknown, but may parallel the response to other cellular stresses, such as heat shock. After 4-8 h of hypoxia, we found a decrease in total protein synthesis in both cultured bovine aortic and pulmonary arterial EC. SDS-PAGE and autoradiographic analysis of [ ${ }^{35}$ S]methionine-labeled proteins demonstrated the concomitant induction of a specific set of proteins $\left(M_{\mathrm{r}} 34,36,47\right.$, and $\left.56 \mathrm{kD}\right)$ in both cell types. These hypoxia-associated proteins (HAPs) were cell-associated and up-regulated in a time- and oxygen concentration-dependent manner. Comparison of these proteins with heat shock proteins (HSPs) demonstrated that HAPs were distinct from HSPs. EC maintained chronically in $3 \% \mathrm{O}_{2}$ continued to synthesize elevated levels of HAPs, yet further up-regulated these proteins when exposed to $0 \% \mathrm{O}_{2}$. The presence of five times the normal media glucose concentration did not alter the appearance of HAPs. Hypoxia sensitive renal tubular epithelial cells up-regulated no proteins corresponding to $\mathrm{HAPs}$ and were irreversibly damaged within $8 \mathrm{~h}$ of exposure to $0 \% \mathrm{O}_{2}$. In vitro translation experiments demonstrated that the steady-state level of several mRNAs was higher in the anoxic EC than in normoxic EC and encoded for proteins of $M_{\mathrm{r}} 32,35,37,40$, and $48 \mathrm{kD}$ that were different from proteins encoded by HSP mRNAs. The induction of HAPs during acute hypoxia and their continued synthesis in chronic hypoxia suggest that HAPs may be important in the maintenance of endothelial cell integrity under conditions of decreased ambient oxygen. (J. Clin. Invest. 1991. 87:908914.). Key words: anoxia • chronic hypoxia • heat shock proteins • in vitro translation • vascular endothelium
\end{abstract}

\section{Introduction}

Owing to their anatomical location, endothelial cells (EC) ${ }^{1}$ are the initial cells within the vascular wall to be exposed to de-

This work was presented in part at the May 1989 American Thoracic Society meeting and published in abstract form (1989. Am. Rev. Respir. Dis. 139:A170).

Dr. Zimmerman's current address is: 111D-Respiratory Care Section, San Francisco Veterans Administration Medical Center, San Francisco, CA 94121.

Address reprint requests to Dr. Farber, Pulmonary Center, Boston University School of Medicine, 80 East Concord Street, K-603, Boston, MA 02118.

Received for publication 23 April 1990 and in revised form 4 October 1990.

1. Abbreviations used in this paper: EC, endothelial cells; GRP, glucose-regulated protein; HAP, hypoxia-associated protein; HSP, heat shock protein.

J. Clin. Invest.

(c) The American Society for Clinical Investigation, Inc. 0021-9738/91/03/0908/07 \$2.00

Volume 87, March 1991, 908-914 creases in blood ambient oxygen concentration. Normally, the pulmonary endothelium is exposed to the lower oxygen content of mixed venous blood; in pathologic states, aortic and pulmonary artery EC may be exposed to markedly decreased blood oxygen content. Thus, adaptation and tolerance to acute and chronic hypoxia may be a fundamental property of these cells. In support of this concept, we and others have demonstrated that cultured vascular EC subjected to severe hypoxia exhibit changes in metabolic function (1-7), yet retain their cellular integrity $(2,5,7)$.

The mechanisms by which EC preserve their integrity and cellular functions during decreases in ambient oxygen concentration are unknown but may parallel the response to other stresses, such as heat shock (8). Exposure to elevated temperature leads to a decrease in total protein synthesis, with concomitant induction of specific proteins, and eventual cell death if the insult is unremitting. Nonlethal temperature elevation rapidly induces a family of highly conserved proteins termed heat shock proteins (HSPs), which appear to be linked to the phenomenon of thermotolerance, i.e., the enhanced survival of cells exposed to a subsequent potentially lethal heat stress (913). Previous studies (14-18) have shown that exposure to anoxia also leads to the enhanced production of proteins, termed oxygen-regulated proteins or anoxia stress proteins; however, these proteins vary depending on the cell line examined and are usually associated with co-induction of HSPs and/or another family of stress proteins, the glucose-regulated proteins (GRPs) $(13,17,19)$.

In the current study, we characterize a specific set of EC proteins induced by acute and chronic hypoxia that are distinct from HSPs and demonstrate that the control of these proteins is likely to occur at the transcriptional level.

\section{Methods}

$E C$ cultures. Bovine EC were isolated from freshly excised calf aortas and pulmonary arteries as previously described $(2,20)$. EC were obtained by lightly scraping the intimal surface of longitudinally opened vessels; cells were seeded initially into 60 -mm plastic dishes (Costar, Cambridge, MA) with growth media containing MEM (Gibco Laboratories, Grand Island, NY) supplemented with $15 \%$ heat-inactivated calf serum (CS) (Hyclone Laboratories, Logan, UT), 1 mM sodium pyruvate (Gibco Laboratories), penicillin and streptomycin (Sigma Chemical Co., St. Louis, MO). Cultures were maintained in a humidified incubator at $37^{\circ} \mathrm{C}$ in $95 \%$ air $/ 5 \% \mathrm{CO}_{2}$ and were identified as endothelial cells by typical cobblestone appearance, factor VIII immunofluorescence, and angiotensin-converting enzyme activity $(2,20)$. Experiments were performed using aortic and pulmonary arterial EC of passages 5-12. Within each experiment, EC of the same passage from the same primary cell line were used. Experiments examining chronically hypoxic EC used aortic and pulmonary arterial EC maintained from isolation in $3 \% \mathrm{O}_{2} / 5 \% \mathrm{CO}_{2}$ /balance $\mathrm{N}_{2}$ (Medical-Technical Gases, Medford, MA) as previously described $(21,22)$. In these experiments, EC maintained long term in $3 \% \mathrm{O}_{2}$ were compared to EC from the same calf maintained in $95 \%$ air $/ 5 \% \mathrm{CO}_{2}$.

Total protein synthesis. EC monolayers were incubated for 1, 4, 8, or $18 \mathrm{~h}$ with $1 \mathrm{ml}$ of growth media supplemented with $3 \mu \mathrm{Ci} / \mathrm{ml}$ of neutralized ${ }^{3} \mathrm{H}$-amino acid mixture (New England Nuclear, Boston, 
MA). During the experimental period, EC monolayers were either incubated at $37^{\circ} \mathrm{C}$ in $95 \%$ air $/ 5 \% \mathrm{CO}_{2}$ or in a humidified sealed chamber (Billups-Rothenburg, Del Mar, CA) which was gassed with $3 \%$ or $0 \%$ $\mathrm{O}_{2} / 5 \% \mathrm{CO}_{2} /$ balance $\mathrm{N}_{2}$ (Medical-Technical Gases). At the end of the incubation period, the partial pressure of oxygen in the culture medium was measured using a $\mathrm{pH} / \mathrm{blood}$ gas analyzer (Instrumentation Laboratory, Lexington, MA) and was similar to previously described values $(2,22)$. Parallel EC monolayers were assessed for injury by phase microscopic appearance, adherent cell counts, and ${ }^{51} \mathrm{Cr}$ release $(2,22)$. Trichloroacetic acid (TCA)-precipitable protein was measured in the EC monolayers as previously described (20). Amino acid incorporation was expressed as the ratio of counts in TCA-precipitate material divided by the total counts $\times 100 \%$.

Induction and labeling of newly synthesized proteins. Hypoxia-associated proteins (HAPs) were induced by exposing confluent EC monolayers in humidified sealed chambers to $10 \%, 3 \%$, or $0 \% \mathrm{O}_{2} / 5 \% \mathrm{CO}_{2} / \mathrm{bal}-$ ance $\mathrm{N}_{2}$ for $4,8,12$, or $18 \mathrm{~h}$. EC monolayers were subjected to heat stress by sealing $35-\mathrm{mm}$ dishes with parafilm to maintain $\mathrm{CO}_{2}$ and floating them in a temperature-controlled water bath at $43^{\circ} \mathrm{C}$ for $1 \mathrm{~h}$, $45^{\circ} \mathrm{C}$ for $15 \mathrm{~min}$, or $45^{\circ} \mathrm{C}$ for $30 \mathrm{~min}$. Chemical stress was produced by exposing EC monolayers to 10 or $100 \mu \mathrm{M}$ sodium arsenite (Sigma Chemical Co.) in growth media for $1 \mathrm{~h}$ at $37^{\circ} \mathrm{C}$. After the exposure to hypoxia, heat, or arsenite, EC monolayers were either immediately incubated with $1 \mathrm{ml}$ of methionine-free modified Eagle's media (Gibco Laboratories) supplemented with $10 \% \mathrm{CS}, 1 \mathrm{mM}$ sodium pyruvate, and $50 \mu \mathrm{Ci} / \mathrm{ml}$ of $\left[{ }^{35} \mathrm{~S}\right]$ methionine (New England Nuclear) for $1 \mathrm{~h}$ or allowed to recover at $37^{\circ} \mathrm{C}$ in $95 \%$ air $/ 5 \% \mathrm{CO}_{2}$ before labeling with radioactive methionine. For those EC monolayers which were subjected to sodium arsenite, monolayers were washed extensively with phosphate-buffered saline (PBS; pH 7.35, Gibco Laboratories) and incubated with fresh growth media before the recovery period. For the hypoxia-exposed monolayers, recovery periods were 2,4 , or $6 \mathrm{~h}$; for the heat- and arsenite-exposed EC monolayers, recovery periods were 2 or $4 \mathrm{~h}$. Normoxic EC monolayers were labeled in a similar manner. Preliminary experiments demonstrated that the induction of stress proteins was optimal under the following conditions: for hypoxia, $0 \% \mathrm{O}_{2}$ for $18 \mathrm{~h}$ followed by $4 \mathrm{~h}$ of recovery; for heat shock, $45^{\circ} \mathrm{C}$ for $15 \mathrm{~min}$ followed by $2 \mathrm{~h}$ of recovery; for arsenite, $100 \mu \mathrm{M}$ sodium arsenite for 1 $\mathrm{h}$ followed by $2 \mathrm{~h}$ of recovery.

To determine whether these proteins were secreted or remained cell-associated, supernatants were collected and centrifuged at $1,500 \mathrm{~g}$ for $5 \mathrm{~min}$ to remove any cellular debris, and $100 \mu \mathrm{l}$ was added to $100 \mu \mathrm{l}$ of $10 \%$ TCA and $25 \mu \mathrm{l}$ of $5 \mathrm{mg} / \mathrm{ml}$ deoxycholate (Sigma Chemical Co.). This solution was placed on ice for $10 \mathrm{~min}$ and centrifuged at $1,500 \mathrm{~g}$ for $5 \mathrm{~min}$; the pellet was dissolved in $1 \mathrm{ml}$ of ether, vortexed, and centrifuged at $2,000 \mathrm{~g}$ for $15 \mathrm{~min}$. This pellet was lysed in $100 \mu \mathrm{l}$ of lysis buffer $(0.0625 \mathrm{mM}$ Tris, pH $6.8,10 \%$ glycerol, $3 \%$ SDS, $10 \% \beta$-mercaptoethanol). The corresponding EC monolayers were washed with PBS and lysed with $300 \mu \mathrm{l}$ of lysis buffer.

To determine whether long-term exposure to decreased ambient oxygen caused continued production of these HAPs, EC harvested from the same calf were maintained from isolation for months in either $95 \%$ air $/ 5 \% \mathrm{CO}_{2}$ or $3 \% \mathrm{O}_{2}(21,22)$. For experiments, these EC monolayers were continued at the same oxygen level or exposed to $0 \% \mathrm{O}_{2}$ for $18 \mathrm{~h}$ followed by $4 \mathrm{~h}$ of recovery before $\left[{ }^{35} \mathrm{~S}\right]$ methionine labeling and lysis. Alternatively, the EC monolayers chronically grown in $3 \% \mathrm{O}_{2}$ were subjected to $45^{\circ} \mathrm{C}$ for $15 \mathrm{~min}$ and allowed to recover at $37^{\circ} \mathrm{C}$ for 2 $\mathrm{h}$ or incubated with $100 \mu \mathrm{M}$ sodium arsenite for $1 \mathrm{~h}$ and allowed to recover in growth media for $2 \mathrm{~h}$ before $\left[{ }^{35} \mathrm{~S}\right]$ methionine labeling and lysis.

To determine whether HAP expression was related to glucose depletion during glycolysis in the hypoxic cell $(8,13)$, EC monolayers were exposed to $0 \% \mathrm{O}_{2}$ for $18 \mathrm{~h}$ in the presence of normal media glucose concentration $(100 \mathrm{mg} / \mathrm{dl})$ or five times that concentration $(500 \mathrm{mg} /$ $\mathrm{dl})$. The EC were allowed to recover for $4 \mathrm{~h}$ and then labeled with $\left[{ }^{35}\right.$ S $]$ methionine and lysed.

To determine whether hypoxia-sensitive cells, such as renal tubular epithelial cells $(23,24)$, up-regulate similar proteins, cultured mouse renal tubular epithelial cells (courtesy of W. Lieberthal, Boston Univer- sity School of Medicine) were exposed to $0 \% \mathrm{O}_{2}$, allowed to recover, and labeled with $\left[{ }^{35} \mathrm{~S}\right]$ methionine using the same protocol as for EC.

Gel electrophoresis and autoradiography. Cell lysates were collected and boiled for $2 \mathrm{~min}$ before gel electrophoresis. Equal counts of lysate radioactivity were analyzed by $10 \%$ uniform concentration sodium dodecyl sulfate-polyacrylamide gel electrophoresis (SDS-PAGE) (25). Alternatively, gels were loaded with equal volumes or equal amounts of protein of lysate per lane; protein concentration was determined by the method of Peterson (26). Gels were stained with $0.1 \%$ Coomassie Brilliant Blue R-250 in 25\% methanol, $5 \%$ acetic acid, and destained in $25 \%$ methanol and $5 \%$ acetic acid. The gels were dried and exposed to $x$-ray film (XAR-5, Eastman Kodak Co., Rochester, NY) with exposure times of 2-7 d. Induced protein bands were quantitated by densitometry (laser densitometer, LKB Produkter, Bromma, Sweden).

RNA isolation and in vitro translation. Cytoplasmic RNA was isolated by the method of Favaloro et al. (27) modified by Levine et al. (28) from EC maintained in $95 \%$ air $/ 5 \% \mathrm{CO}_{2}$, EC subjected to $0 \% \mathrm{O}_{2}$ for $18 \mathrm{~h}, \mathrm{EC}$ subjected to $45^{\circ} \mathrm{C}$ for $15 \mathrm{~min}$ followed by $2 \mathrm{~h}$ of recovery, or EC subjected to $100 \mu \mathrm{M}$ sodium arsenite for $1 \mathrm{~h}$ followed by $2 \mathrm{~h}$ of recovery. After extraction with phenol and chloroform, the RNA was precipitated, dissolved in water, and frozen. Quantitation was assessed by absorbance at $260 \mathrm{~nm}$. Equal aliquots of total RNA were translated in a rabbit reticulocyte in vitro translation system (Bethesda Research Laboratories, Gaithersburg, MD) using $30 \mu \mathrm{Ci}$ of $\left[{ }^{35} \mathrm{~S}\right]$ methionine per sample. Translation products were analyzed by SDS-PAGE and autoradiography.

\section{Results}

Total protein synthesis. Incubation of aortic and pulmonary arterial EC monolayers maintained in $95 \%$ air $/ 5 \% \mathrm{CO}_{2}$ with a ${ }^{3} \mathrm{H}$-amino acid mix showed an expected time-dependent increase in incorporation of label into TCA-precipitable protein (Fig. 1). A > 10-fold increase in ${ }^{3} \mathrm{H}$-amino acid incorporation was measured in both cell lines after $18 \mathrm{~h}$ of continuous labeling. Protein synthesis in EC monolayers exposed to $3 \%$ or $0 \%$ $\mathrm{O}_{2}$ was decreased, with the greatest inhibition occurring in both cell types incubated in $0 \% \mathrm{O}_{2}$. The decrease in protein synthesis was evident by $4 \mathrm{~h}$ and increased as the exposure to hypoxia continued, such that the ${ }^{3} \mathrm{H}$-amino acid incorporation had in-

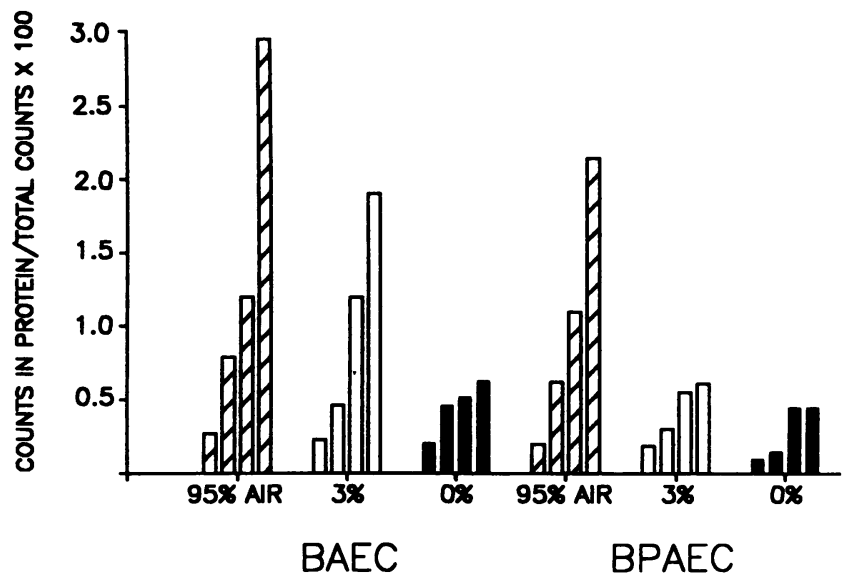

Figure 1. Total protein synthesis in EC exposed to hypoxia. In this representative experiment, bovine aortic (BA) and pulmonary arterial (BPA) EC were incubated continuously with ${ }^{3} \mathrm{H}$-amino acid mixture in $95 \%$ air, $3 \% \mathrm{O}_{2}$, or $0 \% \mathrm{O}_{2}$ for $1,4,8$, or $18 \mathrm{~h}$, respectively, and the monolayer protein was precipitated by TCA. Protein synthesis was expressed as the ratio of counts in the TCA-precipitable material divided by the total counts $\times 100(\%)$. 


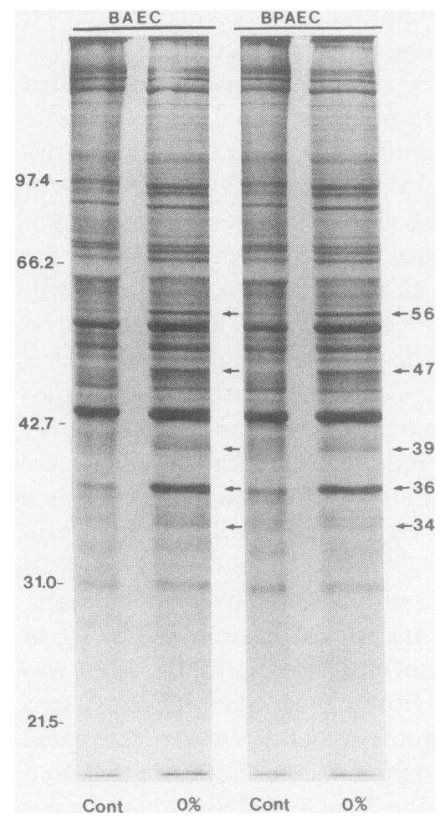

Figure 2. Effect of anoxia on the protein profiles of EC, BAEC and BPAEC were either maintained in $95 \%$ air (Cont) or exposed to $0 \% \mathrm{O}_{2}$ for $18 \mathrm{~h}$ and allowed to recover in $95 \%$ air for $4 \mathrm{~h}(0 \%)$, then pulselabeled with $\left[{ }^{35} \mathrm{~S}\right]$ methionine for $1 \mathrm{~h}$. Equal counts of radioactivity loaded per lane were analyzed by $10 \%$ SDSPAGE and autoradiography. HAPs are indicated by arrows and their molecular masses are shown on the right. Molecular mass standards are indicated on the left. All molecular mass values are given in kilodaltons.

creased only three- to fourfold after $18 \mathrm{~h}$ of continuous labeling. Despite this decrease in total protein synthesis, there was no evidence of EC injury as determined by phase microscopic appearance, adherent cell counts, or ${ }^{51} \mathrm{Cr}$ release (data not shown).

Induction of HAPs. Despite a marked reduction in total protein synthesis in EC monolayers exposed to $0 \% \mathrm{O}_{2}$ over 18 $\mathrm{h}$, there was induction of a specific family of proteins as shown by autoradiographs of $\left[{ }^{35} \mathrm{~S}\right]$ methionine-labeled polypeptides separated by SDS-PAGE (Fig. 2). These induced proteins had an apparent $M_{\mathrm{r}}$ of $34,36,39,47$, and $56 \mathrm{kD}$. All five proteins were present at low levels in normoxic EC, but were induced at least two- to fourfold as measured by densitometric analysis in both aortic and pulmonary arterial cell lines after hypoxia. Although there was slight variability in the degree of induction of the proteins, the 34-, 36-, 47-, and 56-kD HAPs were induced in all experiments; the $39-\mathrm{kD}$ protein was not apparent in some experiments. Increased synthesis of these proteins was apparent on autoradiographs of polyacrylamide gels whether they were loaded by equal counts of radioactivity, equal volumes, or equal protein of lysate (data not shown). At least two proteins of $M_{\mathrm{r}} 35$ and $180 \mathrm{kD}$ were specifically down-regulated in response to hypoxia.

Up-regulation of these proteins was dependent on the duration of hypoxia; synthesis was slightly increased at $4 \mathrm{~h}$, and became maximal at 12-18 h (Fig. 3). Under these conditions, no additional enhancement was noted after this time period despite continued hypoxia to $48 \mathrm{~h}$ (data not shown). Of note, in every experiment, these proteins were maximally up-regulated only after total protein synthesis had fallen in response to hypoxia and were identical in both aortic and pulmonary arterial EC. Induction of these proteins was also dependent on the severity of hypoxia; the synthesis of these proteins increased as the ambient oxygen concentration decreased (Fig. 4). Comparison of proteins found in supernatants and cell lysates of EC monolayers exposed to $0 \% \mathrm{O}_{2}$ demonstrated no proteins upregulated by hypoxia in the supernatants (data not shown).

Comparison of the proteins induced by hypoxia to those induced by either hyperthermia or exposure to sodium arsenite demonstrated that HAPs were distinct from HSPs (Fig. 5). Hyperthermia increased the synthesis of proteins at $M_{\mathrm{r}} 68,70,90$, and $110 \mathrm{kD}$, whereas sodium arsenite increased the synthesis of proteins at $M_{\mathrm{r}} 32,38,68,70,90$, and $110 \mathrm{kD}$. These corresponded to conventional HSPs $(11,29,30)$ and had different molecular masses from those of HAPs.

EC maintained long-term in $3 \% \mathrm{O}_{2}$ proliferated and retained markers and appearance of typical cultured $\operatorname{EC}(21,22)$. Chronically hypoxic EC demonstrated persistently elevated levels of HAPs (Fig. 6). When these chronically hypoxic EC were exposed acutely to $0 \% \mathrm{O}_{2}$, HAPs were further up-regulated. In addition, exposure of these chronically hypoxic cells to heat- or arsenite-induced HSPs that were identical to the HSPs induced in normoxic cells.

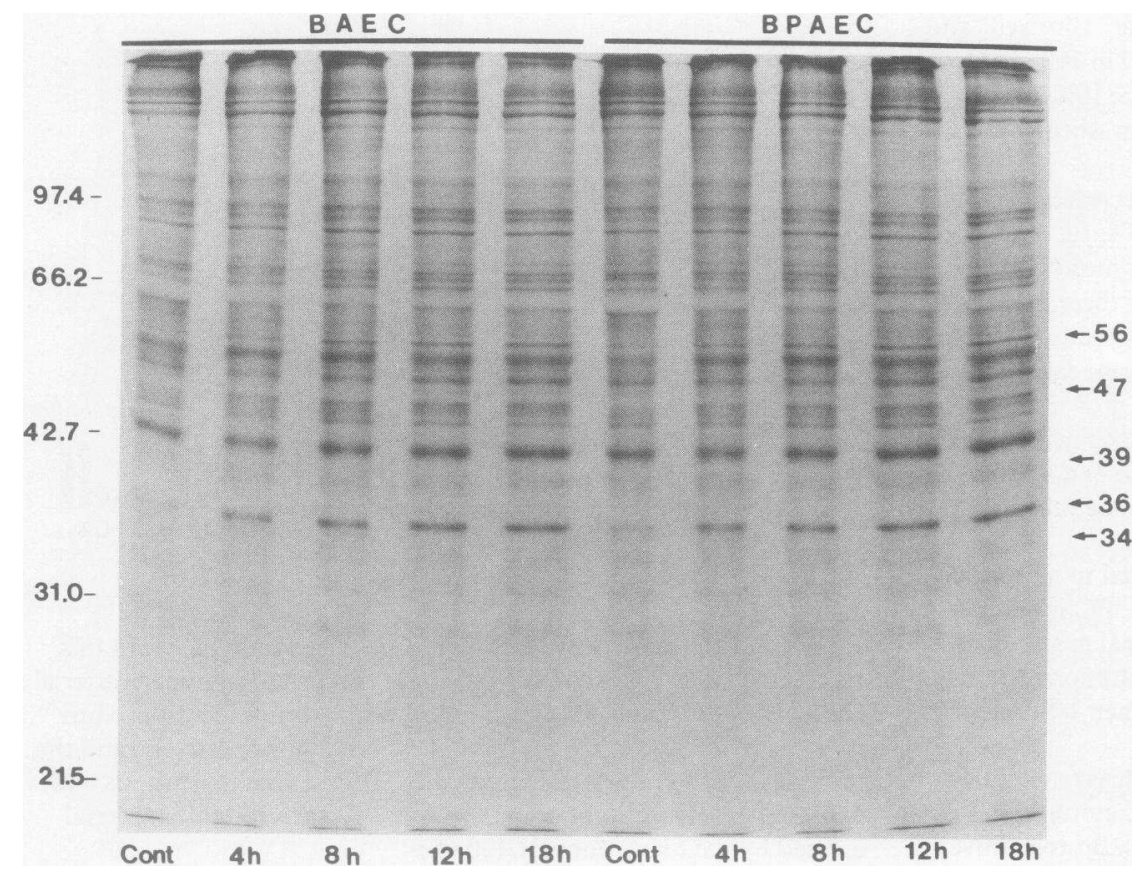

Figure 3. Time course of induction of HAPs. BAEC and BPAEC were either maintained in $95 \%$ air (Cont) or exposed to $0 \% \mathrm{O}_{2}$ for times indicated and allowed to recover in $95 \%$ air for $4 \mathrm{~h}$, then pulse-labeled with $\left.{ }^{35} \mathrm{~S}\right]$ methionine for $1 \mathrm{~h}$. Equal counts of radioactivity loaded per lane were analyzed by $10 \%$ SDS-PAGE and autoradiography. HAPs are indicated by arrows and their molecular masses are shown on the right. 


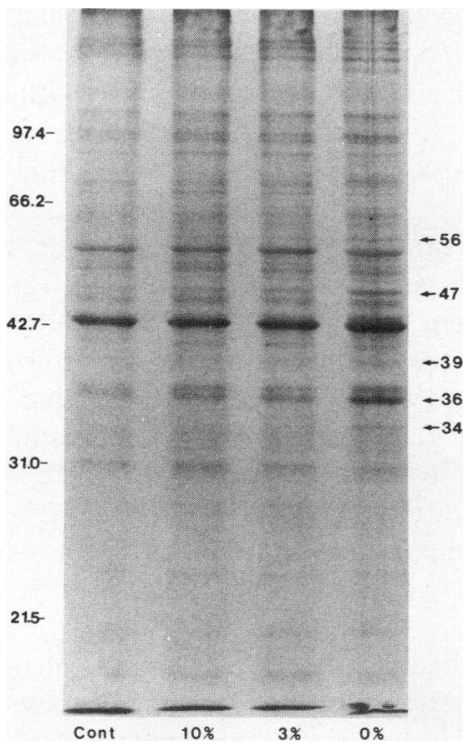

Comparison of the proteins induced by hypoxia in the presence of either normal or elevated media glucose concentrations is shown in Fig. 7. HAPs were up-regulated after exposure to hypoxia in the presence of normal media glucose concentrations $(100 \mathrm{mg} / \mathrm{dl})$. The presence of media containing five times the normal media glucose concentration $(500 \mathrm{mg} / \mathrm{dl})$ did not alter the up-regulation of HAPs, suggesting that exposure to hypoxia, and not glucose depletion, is necessary for induction of these proteins.

Exposure of cultured mouse renal tubular epithelial cells to $0 \% \mathrm{O}_{2}$ caused irreversible damage to these cells within $8 \mathrm{~h}$ (data not shown). No proteins corresponding to HAPs were upregulated during this period (Fig. 8).

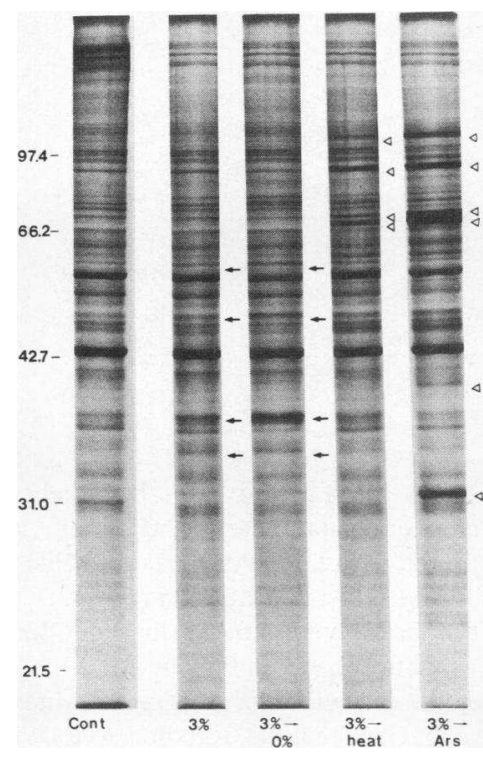

Figure 6. Effect of chronic hypoxia. EC were maintained from isolation in either 95\% air (Cont) or $3 \% \mathrm{O}_{2}(3 \%)$. For experiments, EC maintained at $3 \% \mathrm{O}_{2}$ were either exposed to the same oxygen level or exposed to $0 \% \mathrm{O}_{2}$ for $18 \mathrm{~h}$ and allowed to recover in $95 \%$ air for 4 h. Alternatively, EC maintained at $3 \% \mathrm{O}_{2}$ were exposed to $45^{\circ} \mathrm{C}$ for $15 \mathrm{~min}$ and allowed to recover at $37^{\circ} \mathrm{C}$ for $2 \mathrm{~h}$ (heat), or incubated with $100 \mu \mathrm{M}$ sodium arsenite for $1 \mathrm{~h}$ and allowed to recover in growth media for $2 \mathrm{~h}$ (Ars). Cells were then pulselabeled with $\left[{ }^{35}\right.$ S $]$ methionine for $1 \mathrm{~h}$ and equal counts of radioactivity per lane were analyzed by SDS-PAGE and autoradiography. Only BAEC are shown. HAPs are indicated by arrows and HSPs by open arrowheads; calculated molecular masses were similar to prior figures.

In vitro translation. In vitro translation of RNA indicated that the steady-state level of several mRNAs was higher in EC exposed to $0 \% \mathrm{O}_{2}$ as compared to normoxic EC (Fig. 9). These mRNAs encoded for proteins of $M_{\mathrm{r}} 32,35,37,40$, and $48 \mathrm{kD}$, with the $37-\mathrm{kD}$ encoded protein being the most prominent. The encoded proteins of 35,37 , and $48 \mathrm{kD}$ were of the approximate molecular mass as three of the four consistently present HAPs. No mRNA-encoded protein corresponded to the 56-kD

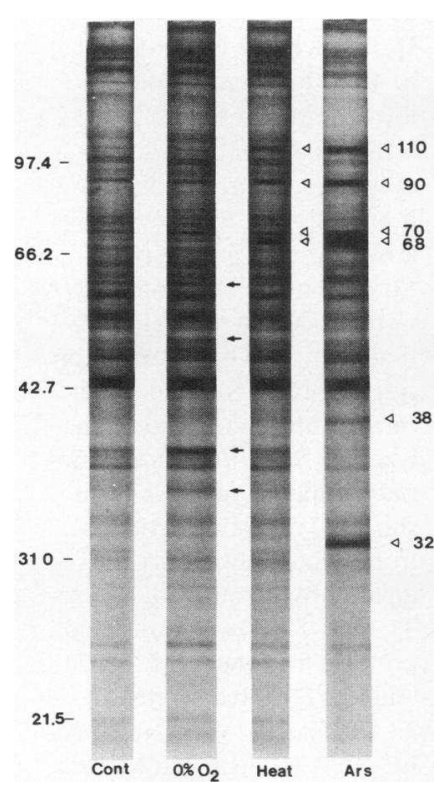

Figure 5. Comparison of HAPs and HSPs. EC were either maintained in $95 \%$ air (Cont), exposed to $0 \% \mathrm{O}_{2}$ for $18 \mathrm{~h}$ and allowed to recover in $95 \%$ air for $4 \mathrm{~h}\left(0 \% \mathrm{O}_{2}\right)$, exposed to $45^{\circ} \mathrm{C}$ for $15 \mathrm{~min}$ and allowed to recover at $37^{\circ} \mathrm{C}$ for $2 \mathrm{~h}$ (Heat), or incubated with 100 $\mu \mathrm{M}$ sodium arsenite for $1 \mathrm{~h}$ and allowed to recover in growth media for $2 \mathrm{~h}$ (Ars). Cells were then pulse-labeled with $\left[{ }^{35}\right.$ S $]$ methionine for $1 \mathrm{~h}$ and equal counts of radioactivity per lane were analyzed by SDS-PAGE and autoradiography. Only BAEC are shown. HAPs are indicated by arrows; their calculated molecular masses are similar to prior figures and are not repeated. HSPs are indicated by open arrowheads and their molecular masses are shown on the right.

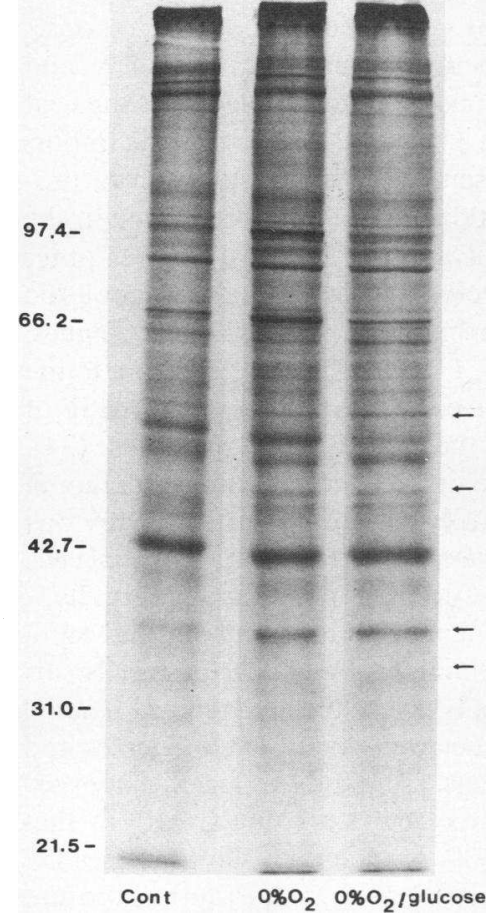

Figure 7. Effect of glucose on induction of HAPs. EC were maintained in $95 \%$ air or exposed to $0 \% \mathrm{O}_{2}$ for 18 $h$ in the presence of normal media concentrations of glucose $\left(0 \% \mathrm{O}_{2}\right)$ or five times that concentration $\left(0 \% \mathrm{O}_{2}\right.$ /glucose). EC were allowed to recover in $95 \%$ air for $4 \mathrm{~h}$ and then pulselabeled with $\left[{ }^{35}\right.$ S $]$ methionine for $1 \mathrm{~h}$. Equal counts of radioactivity per lane were analyzed by SDSPAGE and autoradiography. Only BAEC are shown. HAPs are indicated by arrows; calculated molecular weights were similar to prior figures. 


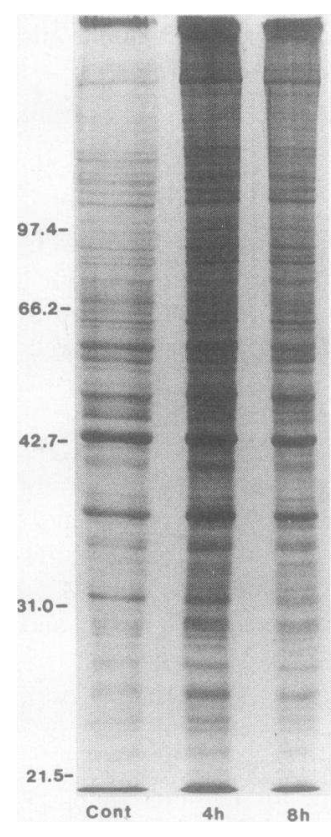

Figure 8. Effect of anoxia on the protein profiles of renal tubular epithelial cells. Cultured mouse renal tubular epithelial cells were either maintained in $95 \%$ air (Cont) or exposed to $0 \% \mathrm{O}_{2}$ for 4 or $8 \mathrm{~h}$, allowed to recover in $95 \%$ air for $4 \mathrm{~h}$, then pulse-labeled with $\left[{ }^{35}\right.$ S]methionine for $1 \mathrm{~h}$. Equal counts of radioactivity per lane were analyzed by $10 \%$ SDSPAGE and autoradiography.

HAP noted on one-dimensional analysis of cell lysates. With the possible exception of the $32-\mathrm{kD}$ protein, these encoded proteins were different from those encoded by mRNA from EC subjected to heat shock $(39,70,71$, and $92 \mathrm{kD})$ or sodium arsenite treatment $(32,39,70,71$, and $92 \mathrm{kD})$.

\section{Discussion}

Prokaryotic and eukaryotic cells respond to a variety of environmental insults by altering their cellular machinery both to down-regulate total protein synthesis and to up-regulate the production of a specific set of polypeptides termed "stress proteins." Best studied are HSPs and the heat shock response; recent studies suggest that these proteins protect, preserve, and recover the functions of various protein complexes during heat shock (reviewed in reference 31 ). HSP 70 appears to be important in the unfolding, disassembly, and translocation of proteins; whereas HSP 60 and possibly HSP 90 participate in the folding and assembly of polypeptides. Several stresses other than heat, such as viral infections, heavy metals, ethanol, the sulfhydryl reagent sodium arsenite, and amino acid analogues, also induce classic HSPs $(11,13,30,32,33)$; in addition to the induction of classic HSPs, arsenite also induces a non-HSP of $32 \mathrm{kD}$, recently identified as the enzyme heme oxygenase (34).

$\mathrm{EC}$ in vivo are exposed to diverse forms of stress, including changes in blood ambient oxygen concentration. Previous work by us and others have demonstrated that endothelial cells in culture are tolerant to short-term anoxia and long-term hypoxia as evidenced by maintenance of their metabolic and cellular integrity (1-7). The mechanisms by which these cells survive during hypoxia have not been established but may parallel the relationship between other well-documented stresses and the induction of stress proteins. Our studies suggest that exposure to decreased levels of oxygen is a true "stress" in that prolonged severe exposure ( $0 \%$ oxygen for $>96 \mathrm{~h}$ ) causes EC death (our unpublished observations), yet short-term exposure to hypoxia or anoxia causes no apparent cellular damage and is associated with the concurrent down-regulation of total protein synthesis and the induction of a specific set of proteins (HAPs). These stress proteins are, however, distinct from the proteins induced by other forms of stress, such as heat shock or sodium arsenite, in the same EC.

Previous work by us and others have demonstrated differences in the production of a neutrophil chemoattractant (2) and a smooth muscle mitogen (7) by aortic and pulmonary artery endothelium in response to short-term anoxia. However, in the current study, there was no difference in the induction of HAPs in these two cell lines in all the parameters examined (time course, degree of hypoxia, levels of mRNA, etc.). While aortic and pulmonary arterial endothelial cells may exhibit differential metabolic responses to hypoxia, the basic response to hypoxia as a "stress" appears to be similar in these two cell lines.

Studies in other mammalian cell lines have demonstrated induction of proteins in response to anoxia. In none of these studies was the protein profile induced by anoxia similar to that of HAPs in EC. For example, EMT6/Ro mouse mammary tumor cells produce proteins of 33,150 , and $260 \mathrm{kD}$ and GRP 80 and GRP 100 (16), rat hippocampal cells produce HSP 68 (15), rat embryo and BALB/c mouse lines produce a $35-\mathrm{kD}$ protein that may be a subunit of lactate dehydrogenase (14), rat fibroblasts produce a $34-\mathrm{kD}$ protein along with GRP 78 and GRP 94 (8), and Chinese hamster ovarian cells transiently increase production of HSP 68-70 and HSP 89 and then produce GRP 76 and GRP 97, and GRP 170 (17, 18). In addition, release from anoxia in $\mathrm{CHO}$ cells induces HSP 68 and HSP 89 (18). In view of the overlap of these anoxia-induced proteins and GRPs, it has been suggested that the induction of GRPs in anoxic conditions is a reflection of depletion of glucose from the media by increased glycolysis in the anaerobic cell $(8,13)$.

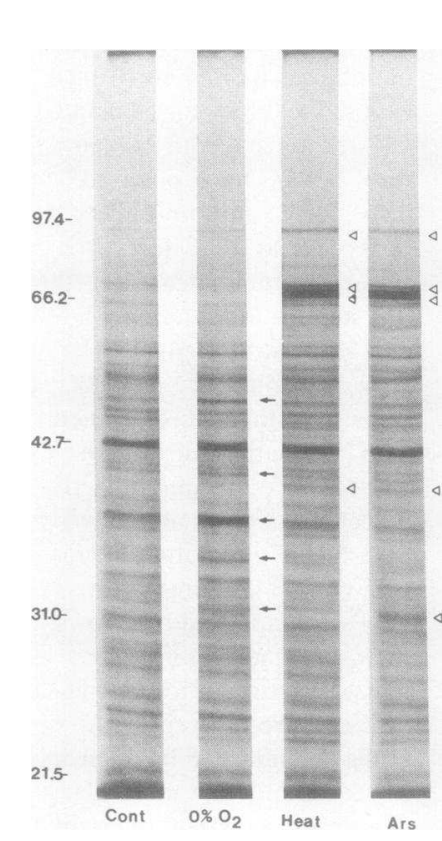

Figure 9. In vitro translation. EC were either maintained in 95\% air (Cont), exposed to $0 \%$ $\mathrm{O}_{2}$ for $18 \mathrm{~h}\left(0 \% \mathrm{O}_{2}\right)$, exposed to $45^{\circ} \mathrm{C}$ for $15 \mathrm{~min}$ and allowed to recover at $37^{\circ} \mathrm{C}$ for 2 $h$ (Heat), or incubated with $100 \mu \mathrm{M}$ sodium arsenite for 1 $h$ and allowed to recover in growth media for $2 \mathrm{~h}$ (Ars). Equal aliquots of isolated RNA were translated in a rabbit reticulocyte in vitro translation system with $\left[{ }^{35}\right.$ S]methionine; translation products were analyzed by SDS-PAGE and autoradiography. Only BAEC are shown. Translated proteins from hypoxic EC RNA are indicated by arrows $\left(M_{\mathrm{r}} 32,35\right.$, 37 , and $48 \mathrm{kD}$ ) and translated proteins from heat $\left(M_{\mathrm{r}} 70,71\right.$, and $92 \mathrm{kD})$ and arsenite $\left(M_{\mathrm{r}}\right.$ $32,70,71$, and $92 \mathrm{kD}$ ) treated EC RNA by open arrowheads. 
In this regard, our studies demonstrate that HAPs synthesis is not suppressed in hypoxic EC incubated with media containing five times the normal concentration of glucose.

Although exposure to $0 \%$ oxygen is lethal after several days, EC are able to survive for months in $3 \%$ oxygen. In fact, these cells continue to proliferate, retain the markers and characteristics of cultured EC, and exhibit no evidence of cellular injury $(21,22)$. The mechanisms by which EC tolerate long-term hypoxia are not known, but it is of interest that chronically hypoxic EC continue to synthesize elevated levels of HAPs. In addition, these cells are capable of greater synthesis of HAPs when exposed acutely to $0 \%$ oxygen. Furthermore, despite the persistent production of HAPs, these chronically hypoxic cells are still capable of responding to another form of stress such as heat shock or arsenite with the induction of typical HSPs. As in EC exposed to acute hypoxia, the HAPs in chronically hypoxic EC are distinct from the stress proteins induced by heat shock or sodium arsenite.

We have designated the proteins induced in these experiments "hypoxia-associated proteins" or HAPs. Previous studies in other cell lines have evaluated protein induction only under anoxic conditions and have termed the induced proteins "anoxia stress proteins" or "oxygen-regulated proteins" (1418). In the current study, we have demonstrated that exposure to both acute and chronic hypoxia (3\% oxygen) as well as acute anoxia up-regulate these proteins and believe that hypoxia-associated proteins is a more specific nomenclature.

Although the function of HAPs is unknown, their induction during acute hypoxia or anoxia, continued synthesis during chronic hypoxia, and further up-regulation when chronically hypoxic EC are exposed to acute anoxia suggests that HAPs may be important in the maintenance of EC integrity under conditions of decreased ambient oxygen. Perhaps, induction of these HAPs might explain why endothelial cells are relatively "hypoxia-tolerant," whereas numerous other cell types such as hepatocytes $(35,36)$, myocardial cells $(37,38)$, and renal tubular cells $(23,24)$ are particularly sensitive to even brief exposure to hypoxia. In support of this concept, our studies demonstrate that exposure to hypoxia causes irreversible damage in cultured renal tubular epithelial cells within $8 \mathrm{~h}$; no new proteins corresponding to HAPs are up-regulated before cell death.

Our work demonstrates that HAPs are different from HSPs and are likely regulated at the RNA level. The steady-state level of several mRNAs was higher in cells exposed to hypoxia, as measured by in vitro translation. Proteins of 35,37 , and $48 \mathrm{kD}$ were of the appropriate molecular mass of three of the four consistently expressed HAPs. We did not detect an in vitro translation product corresponding to the 56-kD HAP. However, owing to the lack of post-translational modification, one of the other hypoxia-inducible in vitro translated proteins may represent this HAP. Alternatively, the induction of the 56-kD protein may represent a translational, rather than a transcriptional, event. Further purification of these proteins and generation of HAP-specific antisera may lead to the identification of a marker for hypoxia in endothelial cells. The development of a marker of the early changes induced in endothelial cells by exposure to hypoxia might have potential application in such clinical entities as atherosclerosis, EC involvement in inflammation, rescue therapies for ischemic heart disease, and radiation therapy resistance in hypoxic tumor cells.

\section{Acknowledgments}

The authors thank Hillary Barnett for technical assistance.

This work was supported by the National Heart, Lung, and Blood Institute Research grant HL-19717.

\section{References}

1. Cummiskey, J. M., L. M. Simon, T. Theodore, U. S. Ryan, and E. D. Robin. 1981. Bioenergetic alterations in cultivated pulmonary artery and aortic endothelial cells exposed to normoxia and hypoxia. Exp. Lung Res. 2:155-163.

2. Farber, H. W., D. M. Center, and S. Rounds. 1987. Effect of decreased ambient oxygen on cultured endothelial cells from different vascular beds. Am. J. Physiol. 253:H878-H883.

3. King, S. J., F. M. Booyse, P. H. Lin, M. Traylor, A. J. Narkates, and S. Oparil. 1989. Hypoxia stimulates endothelial cell angiotensin-converting enzyme antigen synthesis. Am. J. Physiol. 256:C1231-C1238.

4. Krulewitz A. H., and B. L. Fanburg. 1984. The effect of oxygen tension on the in vitro production and release of angiotensin-converting enzyme by bovine pulmonary artery endothelial cells. Am. Rev. Respir. Dis. 130:866-869.

5. Lee, S.-L, and B. L. Fanburg. 1986. Serotonin uptake by bovine pulmonary artery endothelial cells in culture. II. Stimulation by hypoxia. Am. J. Physiol. 250:C766-C770.

6. Pohl, U., and R. Busse. 1989. Hypoxia stimulates release of endotheliumderived relaxant factor. Am. J. Physiol. 256:H1595-H1600.

7. Vender, R. L., D. R. Clemmons, L. Kwock, and M. Friedman. 1987 Reduced oxygen tension induces pulmonary endothelium to release a smooth muscle mitogen(s). Am. Rev. Respir. Dis. 135:622-627.

8. Anderson, G. A., D. L. Stoler, and L. A. Scarello. 1989. Normal fibroblasts responding to anoxia exhibit features of the malignant phenotype. J. Biol. Chem. 264:14885-14892.

9. Carper, S. W., J. J. Duffy, and E. W. Gerner. 1987. Heat shock proteins in thermotolerance and other cellular processes. Cancer Res. 47:5249-5255.

10. Mizzen, L. A., and W. J. Welch. 1988. Characterization of the thermotolerant cell. I. Effects on protein synthesis activity and the regulation of heat-shock protein 70 expression. J. Cell Biol. 106:1105-1116.

11. Schlesinger, M. J. 1986. Heat shock proteins: the search for functions. $J$. Cell Biol. 103:321-325.

12. Sciandra, J. J., and J. R. Subjeck. 1984. Heat shock proteins and protection of proliferation and translation in mammalian cells. Cancer Res. 44:51885194.

13. Subjeck, J. R., and T. T. Shyy. 1986. Stress protein systems of mammalian cells. Am. J. Physiol. 250:C1-C17.

14. Anderson, G. A., K. R. Marotti, and P. A. Whitaker-Dowling. 1979. A candidate rat-specific gene product of the Kirsten murine sarcoma virus. Virology. 99:31-48.

15. Dwyer, B. E., R. N. Nishimura, and I. R. Brown. 1989. Synthesis of the major inducible heat shock protein in rat hippocampus after neonatal hypoxiaischemia. Exp. Neurol. 104:28-31.

16. Heacock, C. S., and R. M. Sutherland. 1986. Induction characteristics of oxygen regulated proteins. Int. J. Radiat. Oncol. Biol. Phys. 12:1287-1290.

17. Sciandra, J. J., J. R. Subjeck, and C. S. Hughes. 1984. Induction of glucose-regulated proteins during anaerobic exposure and of heat-shock proteins after reoxygenation. Proc. Natl. Acad. Sci. USA. 81:4843-4847.

18. Shen, J., C. Hughes, C. Chao, J. Cai, C. Bartels, T. Gessner, and J. Subjeck. 1987. Coinduction of glucose-regulated proteins and doxorubicin resistance in Chinese hamster cells. Proc. Natl. Acad. Sci. USA. 84:3278-3282.

19. Lee, A. S. 1987. Coordinated regulation of a set of genes by glucose and calcium ionophores in mammalian cells. Trends Biochem. Sci. 12:20-23.

20. Farber, H. W., P. F. Weller, S. Rounds, D. J. Beer, and D. M. Center. 1986. Generation of lipid neutrophil chemoattractant activity by histamine-stimulated endothelial cells. J. Immunol. 137:2918-2924.

21. Farber, H. W. Differences in pulmonary and systemic arterial endothelial cell adaptation to chronic hypoxia. In Response and Adaptation to HypoxiaOrgan to Organelle. L. Sukhamay and N. S. Cherniak, editors. Oxford University Press, New York. In press.

22. Farber, H. W., and S. Rounds, with the technical assistance of $H$. F. Barnett. 1990. Effect of long-term hypoxia on cultured aortic and pulmonary arterial endothelial cells. Exp. Cell Res. 191:27-36.

23. Venkatachalam, M. A., D. B. Bernard, J. F. Donahue, and N. G. Levinsky. 1978. Ischemic damage and repair in the rat proximal tubule: differences among the $S_{1}, S_{2}$, and $S_{3}$ segments. Kidney Int. 14:31-49.

24. Kreisberg, J. I., J. W. Mills, J. A. Jarrell, C. A. Rabito, and A. Leaf. 1980. Protection of cultured renal tubular epithelial cells from anoxic cell swelling and cell death. Proc. Natl. Acad. Sci. USA. 77:5445-5447. 
25. Laemmli, U. K. 1970. Cleavage of structural proteins during the assembly of the head of bacteriophage T4. Nature (Lond.). 277:680-685.

26. Peterson, G. L. 1977. A simplification of the protein assay method of Lowry et al. which is more generally applicable. Anal. Biochem. 83:346-356.

27. Favaloro, J., R. Triesman, and R. Kamen. 1980. Transcription maps of polyoma virus-specific RNA: analysis by two-dimensional nuclease S1 gel mapping. Methods Enzymol. 65:718-749.

28. Levine, R. A., J. E. McCormack, A. Buckler, and G. E. Sonenshein. 1986. Transcriptional and posttranscriptional control of c-myc gene expression in WEHI 231 cells. Mol. Cell. Biol. 6:4112-4116.

29. Ketis, N. V., R. L. Hoover, and M. J. Karnovsky. 1988. Effects of hyperthermia on cell survival and patterns of protein synthesis in endothelial cells from different origins. Cancer Res. 48:2101-2106.

30. Levinson, W., H. Oppermann, and J. Jackson. 1980. Transition series metals and sulfhydryl reagents induce the synthesis of four proteins in eukaryotic cells. Biochim. Biophys. Acta. 606:170-180.

31. Schlesinger, M. J. 1990. Heat shock proteins. J. Biol. Chem. 265:1211112114.
32. Laszlo, A. 1988. The relationship of heat-shock proteins, thermotolerance, and protein synthesis. Exp. Cell Res. 178:401-414.

33. Tomasovic, S. P., L. S. Ramagli, R. A. Simonette, M. J. Wilson, and L. V. Rodriguez. 1987. Heat-stress proteins of rat lung endothelial and mammary adenocarcinoma cells. Radiat. Res. 110:45-60.

34. Keyse, S. M., and R. M. Tyrell. 1989. Heme oxygenase is the major 32-kDa protein induced in human skin fibroblasts by UVA radiation, hydrogen peroxide, and sodium arsenite. Proc. Natl. Acad. Sci. USA. 86:99-103.

35. Anundi, I., and H. De Groot. 1989. Hypoxic liver cell death: critical $\mathbf{P O}_{2}$ and dependence of viability on glycolysis. Am. J. Physiol. 257:G58-G64.

36. Herman, B., A. L. Nieminen, G. J. Gores, and J. L. Lemasters. 1988. Irreversible injury in anoxic hepatocytes precipitated by an abrupt increase in plasma membrane permeability. FASEB (Fed. Am. Soc. Exp. Biol.) J. 2:146-151.

37. Hearse, D. J., and E. B. Chain. 1972. The role of glucose in the survival and 'recovery' of the anoxic isolated perfused rat heart. Biochem. J. 128:11251133.

38. Schwartz, P., H. M. Piper, R. Spahr, and P. G. Spieckermann. 1984. Ultrastructure of cultured adult myocardial cells during anoxia and reoxygenation. Am. J. Pathol. 115:349-361. 